\title{
A Graphical User Interface as a DSS Tool for GHG Emission Estimation from Water Resource Recovery Facilities
}

\author{
L. Frunzo ${ }^{1(\bowtie)}$, G. Esposito ${ }^{2}$, R. Gori ${ }^{3}$, D. Caniani ${ }^{4}$, M. Caivano ${ }^{4,5}$, \\ A. Cosenza $^{6}$, and G. Mannina ${ }^{6}$ \\ ${ }^{1}$ Department of Mathematics and Applications "R. Caccioppoli", \\ University of Naples "Federico II", \\ Via Cintia 1 Complesso Montesantangelo, 80126 Napoli, Italia \\ luigi.frunzo@unina.it \\ 2 Department of Civil and Mechanical Engineering, \\ University of Cassino and Southern Lazio, \\ Via Di Biasio 43, 03043 Cassino (FR), Italy \\ 3 Department of Civil and Environmental Engineering (DICEA), \\ University of Florence, Via Santa Marta 3, 50139 Firenze, Italia \\ riccardo.gori@dicea.unifi.it \\ ${ }^{4}$ School of Engineering, University of Basilicata, \\ Viale dell'ateneo Lucano 10, 85100 Potenza, Italy \\ 5 Department of Civil and Environmental Engineering, \\ University of California, Irvine, CA 92697-2175, USA \\ ${ }^{6}$ Department of Civil, Environmental, Aerospace, Materials Engineering, \\ University of Palermo, Viale delle Scienze, 90128 Palermo, Italy
}

\begin{abstract}
A Grafical User Interface (GUI) for the greenhouse gas (GHG) emissions from WWTPs based on four models aimed at quantifying the gas emissions from the aerated tanks (i.e. CAS and MBR reactor), aerobic digesters, secondary clarifiers and anaerobic digesters have been englobed in a GUI in order to provide a valid decision support system (DSS) to the practitioners. The GUI allows to estimate such emissions for the different WWTP phases considered. The GUI has been developed on MATLAB platform and provides as output the GHG emissions in terms of $\mathrm{CO}_{2}$ and $\mathrm{N}_{2} \mathrm{O}$ fluxes.
\end{abstract}

Keywords: Graphical user interface · DSS · Greenhouse gas · Urban wastewater treatment plant

\section{Introduction}

For most of engineering applications, mathematical models can represent valuable support tools as they provide useful information for the decisional process without the time, cost and risk of an experimental activity. For instance, in the environmental applications, mathematical models can be used to estimate (GHG) emissions from the different sections of a wastewater treatment plant (WWTP) (Flores-Alsina et al. 2011; Corominas et al. 2012). However, in most of the cases mathematical models come in complex form and thus are not accessible to practical users. In this work, four models aimed at quantifying 


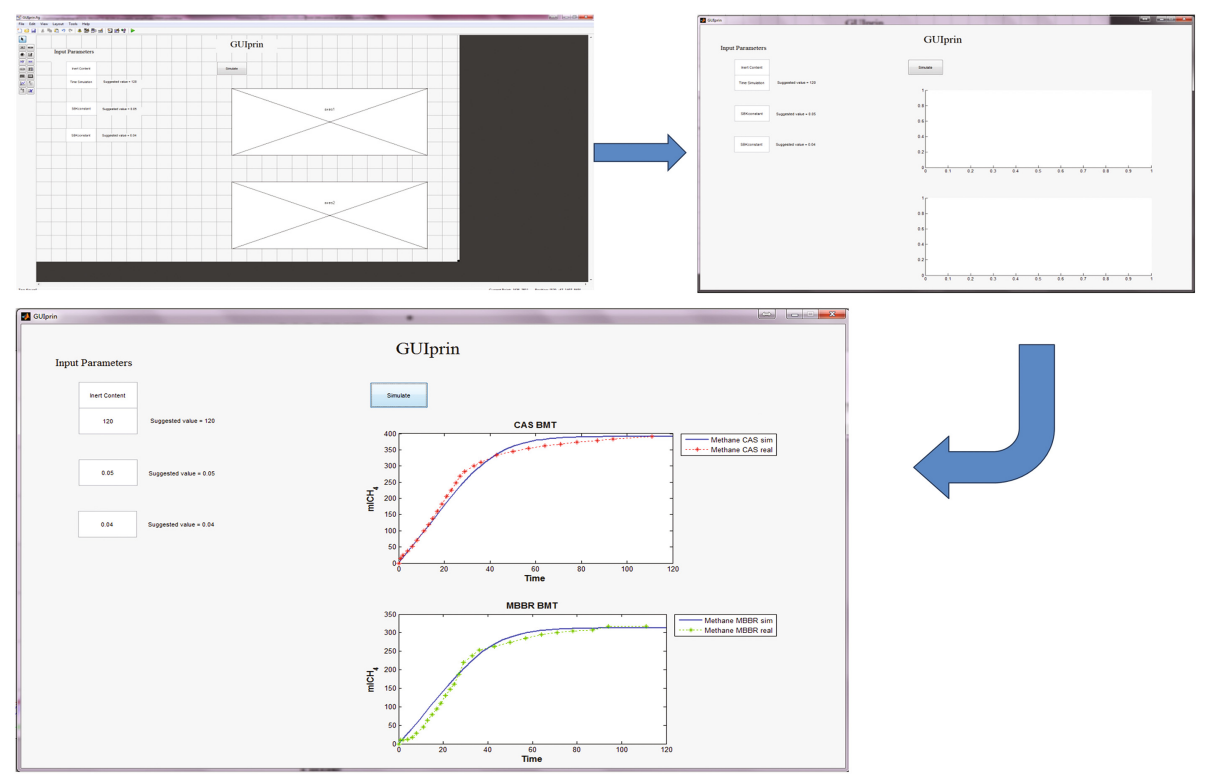

Fig. 1. Procedure for GUI development

the gas emissions from the aerated tanks (i.e. CAS and MBR reactor), aerobic digesters, secondary clarifiers and anaerobic digesters are englobed in a GUI in order to provide a valid decision support system (DSS) to the practitioners (Fig. 1).

\section{Mathematical Models Implemented in the GUI}

\subsection{Aerated Tanks}

\section{Estimation of indirect internal GHG emissions}

The contribution of aeration systems in the indirect internal emission of $\mathrm{CO}_{2}$ per day $(\mathrm{kgCO}$, eq $/ \mathrm{d})$ for an urban wastewater treatment plants (WWTPs) can be evaluated from (Redmon et al. 1983):

$$
\left[\frac{k g C O_{2, e q}}{d}\right]=k \int P_{w} d t
$$

where:

$P_{w}$ is the $P_{w}$ is the blower break horsepower $(\mathrm{kW})$,

In cases of a WWTP where the power demand, energy consumption and air flow-rate of aeration systems are not monitored (very frequent situation on the Italian territory), the off-gas method was observed to be a valid tool for estimating indirect internal emissions. The total air flow $\left(\mathrm{Q}_{\text {tot }}\right)$ blown through the tank surface, given by the weighted average of the different measurements over tank surface, allows to derive the actual power $\left(P_{w}\right)$ used by blowers with the adiabatic compression formula (Eq. 2 ). 


$$
\mathrm{P}_{\mathrm{w}}(\mathrm{kW})=\frac{\mathrm{Q}_{\mathrm{tot}} \cdot \mathrm{P}_{1}}{17.4 \cdot \mathrm{e}_{\mathrm{M}} \cdot \mathrm{e}_{\mathrm{B}}} \cdot\left[\left(\frac{\mathrm{P}_{2}}{\mathrm{P}_{1}}\right)^{0.283}-1\right]
$$

where:

$\mathrm{Q}_{\text {tot }}$ is the total air flow rate $\left(\mathrm{m}^{3} / \mathrm{min}\right)$,

$\mathrm{e}_{\mathrm{M}}$ is the motor efficiency (dimensionless),

$\mathrm{e}_{\mathrm{B}}$ is the blower efficiency (dimensionless),

$\mathrm{P}_{1}$ and $\mathrm{P}_{2}$ are the inlet and outlet absolute pressure $(\mathrm{kPa})$, respectively

Specifications of the blower $\mathrm{P}_{2}$ can be derived from the relative characteristic curve ( $\mathrm{P} 1$ is always $\sim 0.95$ of the atmospheric pressure due to the inlet suction).

Estimation of direct emissions due to bacterial respiration

In the calculation of the $\mathrm{CO}_{2}$ direct emission due to microbial respiration in ASP, it is important to highlight the carbon emission intensity of COD (i.e. the amount of $\mathrm{CO} 2$ emitted per unit of COD oxidised, or kCOD). If wastewater organic compounds could be represented through the formula $\mathrm{C}_{10} \mathrm{H}_{19} \mathrm{O}_{3} \mathrm{~N}$ (widely used for the case of domestic wastewater) we obtain that $\mathrm{k}_{\mathrm{COD}}=0.99 \mathrm{~kg}_{\mathrm{CO} 2 \mathrm{eq}} / \mathrm{kg}_{\mathrm{COD}}$. Analogously, in case of activated sludge biomass, we obtain that $\mathrm{kBIOMASS}=1.03 \mathrm{~kg} \mathrm{CO}_{\mathrm{eq}} / \mathrm{kg}_{\mathrm{COD}}$.

Estimation of $\mathrm{N}_{2} \mathrm{O}$ emissions with MBR technology

$\mathrm{N}_{2} \mathrm{O}$ flux due to the MBR $\left(\mathrm{N}_{2} \mathrm{O}\right.$, basis of the membrane Fouling Rate (FR) according to (Mannina et al. 2015):

$$
\mathrm{N}_{2} \mathrm{O}, \mathrm{MBR}=0.02 \mathrm{FR}^{\wedge} 1.93
$$

\subsection{Aerobic digesters (AeD) and secondary clarifiers}

The relationships for both $\mathrm{N}_{2} \mathrm{O}$ and $\mathrm{CO}_{2}$ produced and emitted in aerobic digesters (AeD) and secondary clarifiers in WWTPs and the available measured data of wastewater and sludge characteristics has been determinated through multiregression analysis. Two different types of correlation analysis have been carried out, i.e. a simple linear regression analysis and a complex regression analysis. The simple regression method consists of testing the simple linear equation to find a relationship between the dependent variable $(\mathrm{Y})$ and the independent variable $(\mathrm{X})$, as in Eq. 1:

$$
\mathrm{Y}=\mathrm{c}_{1} \cdot \mathrm{X}+\mathrm{c}_{2}
$$

where $c_{1}$ and $c_{2}$ are the regression coefficients. The coefficient of determination $\left(\mathrm{R}^{2}\right)$ has been also evaluated to provide a measure of how well observed outcomes are fitted by the empirical model.

Estimation of emission from aerobic digesters (AeD)

Regarding the aerobic digestion, the simple regression method has been performed by considering, as dependent variables $(\mathrm{Y}): \mathrm{N}_{2} \mathrm{O}$ and $\mathrm{CO}_{2}(\mathrm{ppm})$ emissions from the pilot digester. The independent variables $(\mathrm{X})$ taken into account are summarized in Table 1. 
Table 1. Independent variables taken into account during the simple regression analysis on AeD data

\begin{tabular}{|c|c|c|}
\hline Symbol & Definition & Unit \\
\hline $\mathrm{NH}_{4 \text { in }}$ & Influent concentration of ammonia & $\mathrm{mg} / \mathrm{l}$ \\
\hline $\mathrm{NO}_{3 \text { in }}$ & Influent concentration of nitrate & $\mathrm{mg} / \mathrm{l}$ \\
\hline $\mathrm{COD}_{\text {in }}$ & Influent concentration of COD & $\mathrm{mg} / \mathrm{l}$ \\
\hline $\mathrm{NH}_{4 \mathrm{in}, \mathrm{AeD}}$ & Ammonia concentration in AeD influent & $\mathrm{mg} / \mathrm{l}$ \\
\hline $\mathrm{NO}_{3 \mathrm{in}, \mathrm{AeD}}$ & Nitrate concentration in AeD influent & $\mathrm{mg} / \mathrm{l}$ \\
\hline $\mathrm{COD}_{\mathrm{in}, \mathrm{AeD}}$ & COD concentration in AeD influent & $\mathrm{mg} / \mathrm{l}$ \\
\hline $\mathrm{NH}_{4 \text { out,AeD }}$ & Ammonia concentration in AeD effluent & $\mathrm{mg} / \mathrm{l}$ \\
\hline $\mathrm{NO}_{3 \text { out }, \mathrm{AeD}}$ & Nitrate concentration in AeD effluent & $\mathrm{mg} / \mathrm{l}$ \\
\hline $\mathrm{COD}_{\text {out,AeD }}$ & COD concentration in AeD effluent & $\mathrm{mg} / \mathrm{l}$ \\
\hline DO & Dissolved oxygen in AeD & $\mathrm{mg} / \mathrm{l}$ \\
\hline
\end{tabular}

The regression analysis has been carried out by considering the data recorded during experimental campaigns on the pilot digester developed by the Research Group of the Engineering School at the University of Basilicata, using the secondary settler underflow of a full-scale WWTP as digester feeding (Caniani et al. 2015; Caivano et al. 2017a).

\section{Estimation of emission from secondary clarifiers}

Regarding the secondary clarifier, the simple regression method has been performed by considering the following dependent variables (Y): $\mathrm{N}_{2} \mathrm{O}$ and $\mathrm{CO}_{2}(\mathrm{ppm})$ emissions from settler tank $\left(\mathrm{N}_{2} \mathrm{O}_{(\mathrm{g})}\right.$ and $\left.\mathrm{CO}_{2(\mathrm{~g})}\right)$, and $\mathrm{N}_{2} \mathrm{O}$ and $\mathrm{CO}_{2}(\mathrm{mg} / \mathrm{l})$ dissolved in the liquid effluent of the settler $\left(\mathrm{N}_{2} \mathrm{O}_{(1)}\right.$ and $\left.\mathrm{CO}_{2(1)}\right)$. The independent variables $(\mathrm{X})$ summarized in Table 2 have been taken into account.

Table 2. Independent variables taken into account during the simple regression analysis on clarifier data

\begin{tabular}{l|l|l}
\hline Symbol & Definition & Unit \\
\hline $\mathrm{NH}_{4 \text { in,se }}$ & Ammonia concentration in clarifier influent & $\mathrm{mg} / \mathrm{l}$ \\
\hline $\mathrm{NO}_{3 \text { in,se }}$ & Nitrate concentration in clarifier influent & $\mathrm{mg} / \mathrm{l}$ \\
\hline $\mathrm{NO}_{2 \text { in,se }}$ & Nitrite concentration in clarifier influent & $\mathrm{mg} / \mathrm{l}$ \\
\hline $\mathrm{TSS}$ & Total suspended solid in the clarifier & $\mathrm{mg} / \mathrm{l}$ \\
\hline $\mathrm{NH}_{2} \mathrm{OH}$ & Hydroxylamine concentration in clarifier influent & $\mathrm{mg} / \mathrm{l}$ \\
\hline Wind speed & Simulated wind speed on the tank liquid surface & $\mathrm{m} / \mathrm{s}$ \\
\hline
\end{tabular}

The regression analysis has been carried out by considering the data recorded during experimental campaigns on the pilot clarifier developed by the Research Group of the Engineering School at the University of Basilicata, using the secondary settler underflow of a full-scale WWTP as pilot tank feeding, as well as the data recorded on the full scale-settler itself (Caivano et al. 2017b). 


\subsection{Anaerobic digesters}

\section{Estimation of emission from Anaerobic digester}

Emission from Anaerobic digestion has been evaluated through a mathematical model based on differential mass balance equations for the substrates and the products of the process. A single substrate has been taken into account (Organic matter, considered as COD), the overall velocity of the whole anaerobic digestion process has been hypothesized to be equal to hydrolysis velocity of the complex macromolecules. In particular, a modified version of surfaced based kinetic (SBK) approach has been used.

The mathematical model is constituted by the following system of ordinary differential equation:

$$
\begin{aligned}
& \frac{d S}{d t}=-K_{s b k} a^{*} \frac{S}{K_{s}+S} \\
& \frac{d P}{d t}=\sigma K_{s b k} a^{*} \frac{S}{K_{s}+S} \\
& \frac{d X}{d t}=\sigma K_{s b k} a^{*} \frac{S}{K_{s}+S}
\end{aligned}
$$

where:

$S$ is the complex organic substrate mass $[\mathrm{M}]$;

$P$ is the products $\left[\mathrm{L}^{3}\right]$;

$X$ is the microbial biomass [M];

$K_{s b k}=$ disintegration kinetic constant $\left[\mathrm{M} \mathrm{L}^{-2} \mathrm{~T}^{-1}\right]$;

$K=$ like half saturation constant [M]

$\mathrm{N}=$ order of the reaction

$\sigma=$ stoichiometric coefficient

$a^{*}=$ mass-specific disintegration surface area $\left[\mathrm{L}^{2}\right]$;

Assuming that all organic solid particles have the same spherical shape and initial size and they are progressively and uniformly degraded in all directions from the outside towards the inside, the $\mathrm{a}^{*}$ can be determined as follows:

$$
a^{*}=\frac{3}{\mu R}
$$

where:

$\mu$ is the density, while $R$ is the organic solid particles radius, assumed time dependent in according with the following expression

$$
R=R_{0}-K_{s b k} \frac{t}{\mu}
$$

The final $\mathrm{CO}_{2}$ emission has been evaluated considering the complete combustion of the $\mathrm{CH}_{4}$ produced and adding the $\mathrm{CO}_{2}$ produced during the anaerobic digestion process. 


\subsection{Graphic user interface (GUI)}

A GUI for the GHG emissions from WWTPs based on the models proposed in the previous sections has been developed. The GUI allows to estimate such emissions for the different WWTP phases considered. The input parameters to the GUI are represented by independent variables characterising the single models and default input values of input parameters are set. The GUI has been developed on MATLAB platform and provides as output the GHG emissions in terms of $\mathrm{CO}_{2}$ and $\mathrm{N}_{2} \mathrm{O}$ fluxes.

\section{Conclusions}

A GUI for the evaluation of GHGs emissions from WWTP has been developed. For each phase of the WWTP a suitable mathematical model, has been selected and implemented in MATLAB platform. The GUI is able to provide the GHG emissions (dependent variables) by varying the input operational parameters (independent variables).

\section{References}

Caniani D, Esposito G, Gori R, Mannina G (2015) Towards a new decision support system for design, 7 management and operation of wastewater treatment plants for the reduction of greenhouse gases emission. Water (Basel) 7:5599-5616

Caivano M, Masi S, Mancini IM, Caniani D (2017a) Quantification of CO2 and N2O emissions from a pilot-scale aerobic digester, towards the validation and calibration of the first Activated Sludge Model for aerobic digestion (AeDM1). Submitted to FICWTM

Caivano M, Pascale R, Buchicchio A, Mazzone G, Masi S, Mancini IM, Caniani D (2017b) $\mathrm{N}_{2} \mathrm{O}$ and $\mathrm{CO}_{2}$ emissions from secondary settlers in WWTPs: experimental results on full- and pilot scale plants. Submitted to FICWTM

Corominas L, Flores-Alsina X, Snip L, Vanrolleghem PA (2012) Comparison of different modeling approaches to better evaluate greenhouse gas emissions from whole wastewater treatment plants. Biotechnol Bioeng 109(11):2854-2863

Flores-Alsina X, Corominas L, Snip L, Vanrolleghem PA (2011) Including greenhouse gas emissions during benchmarking of wastewater treatment plant control strategies. Water Res. 45(16):4700-4710

Mannina G, Cosenza A (2015) Quantifying sensitivity and uncertainty analysis of a new mathematical model for the evaluation of greenhouse gas emissions from membrane bioreactors. J Membr Sci 475:80-90

Redmon DT, Boyle WC, Ewing L (1983) Oxygen transfer efficiency measurements in mixed liquor using off-gas techniques. Water Pollut Control Fed 55:1338-1347 